\title{
The Analysis of Relationship between Online Contact of Obscene Contents and Real Experience
}

\author{
Chanhee Han, Taehwan Kim, Youngsu Son, and Jinho Yoo
}

\begin{abstract}
As the Internet has developed, it produces adverse effect while provides the convenience in life. Illegal activities which were done through offline in the past are being made mainly through online in the present. Illegal activities are showing greater distribution than when it was distributed offline and illegal and harmful information also spreads easily and rapidly through online. As the Internet has become a part of the life, people are easily exposed to such illegal and harmful information. In this paper, we aim to analyze the correlation between the contact to online illegal harmful information and actual criminal activities. It is analyzed that the relationship between usage of pornographic'prostitution information in the illegal harmful information and that of prostitution establishment. Surveys on 500 Korean people were conducted. Through the analysis, it was shown that getting in contact with pornographic prostitution information significantly affected people to use prostitution establishments. And, some people did not actually use prostitution establishments but were feeling impulsion to using prostitution establishments.
\end{abstract}

Index Terms-Illegal obscene contents, illegal and harmful contents, the adverse effects of the internet.

\section{INTRODUCTION}

As the development of IT technology, including the Internet, that the service was freely available without the constraints of time and place. As a result, South Korea's Internet users are showing an increasing trend every year.

TABLE I: INTERNET USAGE OF KOREA[1]

\begin{tabular}{|c|c|c|c|c|c|c|c|c|c|c|c|}
\hline Year & ‘02 & ‘ 03 & '04 & $\cdot 05$ & ‘06 & ‘07 & ‘ 08 & ‘09 & ' 10 & ' 11 & '12 \\
\hline $\begin{array}{l}\text { Internet } \\
\text { usage }\end{array}$ & 59.4 & 65.5 & 70.2 & 72.8 & 74.1 & 75.5 & 76.5 & 77.2 & 77.8 & 78 & 78.4 \\
\hline
\end{tabular}

Table I shows that Korea's Internet users from $59.4 \%$ in 2002 increased to 78.4 in 2012, Looking at the Korea Internet Security Agency's 2012 survey on the wireless Internet actuality of utilization, on a September 2012 basis, 12 15th $87 \%$ of the population, Appeared to be within the last year mobile phone(including smart phones), laptops with wireless devices such as mobile network(2G/3G), Wi-Fi, Wi-Bro, LTE and other 'wireless Internet services the Wireless Internet users'. Also, wireless Internet usage has increased to $21.8 \%$ compared with $2011(65.2 \%)$, which is constantly increasing [2].

Thus, the reason for an increase in Internet usage, Unlike

Manuscript received October 21, 2013; revised February 17, 2014

The authors are with the Sangmyung University, Republic of Korea (e-mail: gkscks1126@gmail.com; $\quad$ kth11yy@naver.com; neche123@naver.com; jhyoo@smu.ac.kr). the old days almost all over the Internet now can be facilitate for a life, just search and click has can easily find the information. However, The Internet does not mean that only these good functions. In the past, illegal information was disseminated by offline, now is happening mainly online. Thus, the illegal information is influenced on greater than offline distribution. Because using characteristic of online anonymity and supranationality, without national boundaries, it is being quickly and easily distributed.

In recent years, According to SNS services actively used such as Twitter, Facebook, illegal harmful information also distributed through these services, The illegal harmful information of spreading speed has much faster than in the past [3].

In this study, type of illegal harmful information was on the '2012 Korea Communications Standards yearbook' that was classified by Seven kinds items as follow: 1. Gambling, such as betting information What deliberation require high About violation of condition, 2. Illegal food and drug, 3. Prostitution and indecent information, 4. Forgery information, 5. Illegal name trading information, 6. Drug information, 7. Information promotes suicide [4].

Which of these are through the correlation analysis between prostitution, indecent information and using brothels, Recently, there has been an issue in South Korea, And With Act No. 11731 'Act on the Punishment of Acts of Arranging Sexual Traffic', Which prohibits prostitution in South Korea, prostitution, indecent information on this contact is to figure that out how the impact [5].

\section{RELATED WORK}

Kim et al. (2001), who analyzed to cyber pornography contact status of high school students to investigate, In reality the relationship with sexual offenses and were analyzed. According to the study, period as early as pornography offline contacts are more likely to cause sexual offenses yielded results, Who does not get the concept of 'sexual' at a young age, the more exposed pornography to the impact high analyzed. In addition, the contract time and try to pornography, the higher the probability, increase lead to sexual, And Students who have contact with pornography, sexual crimes than those students who were highly experienced. This Internet pornography among adolescents wrong 'gender' concept gives the implications that can be engraved [6].

Park (2007), who analyzed association of between pornography and sexual crime. According to the study, Porn will affect on sexual offenses the claim and not claim that affects the opposition, but claims to be a little more dominant 
refer to as. And the impact of pornography on sexual offenses should be identified clearly claimed that [7].

Kim (2012), who analyzed most offenders committed sexual crimes and pornography that constantly faces. According to the study, the common point between adolescents sexual criminals and adult sexual criminals in sexual criminal motivation, Account for the biggest part for the satisfaction of sexual desires. The second highest motivation was difference, adolescents was cause by curious and adults were drunk. This, Come in contract with against humanity and depravity at old of full curiosity, which can be filled with abnormal sexual concept. According to this study, possibility of sexually deviant behavior yielded by pornography. If not established about right sexual values, Through adults, Can be possibility of sexual crimes, even growing up into adulthood. In addition, the author argued that provider priority punishment and introduced adults blocking system at teenagers use device [8].

Nam and Kim (2012), based on The Social Learning Theory, which is to find out how perceptional factors in terms of mediated effects (self-efficacy, tolerability to sexual violence, sex trade exploitation, and the feeling of sex trade self control), The result showed that adolescents` exposure to internet pornography and perceptual elements such as tolerability to sexual violence, sex trade exploitation, and the feeling of sex trade sex-control have a meaningful effect on deviant sexual activities, sexual violence and the sex trade [9].

Hong and Kim (2012), the study aims to examine how exposure to phonography on the internet affects adolescents behavior toward sexual assault and the sex trade. For this study, the survey was conducted on adolescents. The survey showed that $80 \%$ of adolescents, who were watched on pornographic materials in a year, and man crisis adolescents was more contact pornographic materials than normal adolescents. Respondents contract on average 3-4 type of pornography, which were explained once contract on pornography, which can be prone to contract other types of pornography.

Look at the related work, which were analyzed relationship between prostitution contract and sexual crime mainly for adolescents. In this study the target will be extended to adults, analyze the correlation of use prostitution [10].

\section{METHOD OF INVESTIGATION}

For this study, the survey period is from July 12, 2013 to July 16, 2013. And population was men and women over the age of 13 targets in Korea. At least once within one month with a wired or wireless Internet experienced, And Web survey was conducted in computer-assisted. All through this process has collected 500 valid data.

The survey has proceeded prostitution and indecent information, based on ICT deliberate provision in Article 8: 1. Genital exposure, sexual behavior, similarity Information Act 2. depicting sexual violence (rape depiction, etc.), 3. Information of child pornography. 4. prostitution information was performed by dividing.

Questionnaires was created by four kinds of contact frequency of dirty; prostitution information and experiences with brothel. Analysis of survey results, correlation analysis and two-dimensional cross analysis, using SPSS tools.

\section{RESULTS}

\section{A. The Correlation between Online Contact of Sexual Contents and Act of Prostitution}

\section{1) Correlation analysis}

Table II showed that except for the ages of 13 and 18, more than 60 years old, the rest all of groups has a correlation that P-values less than 0.05 at between contract of sexual contents and utilization of prostitution.

TABLE II: CORRELATION ANALYSIS BETWEEN ONLINE CONTACT OF SEXUAL CONTENTS AND ACT OF PROSTITUTION

\begin{tabular}{ccccc}
\hline \hline & $\begin{array}{c}\text { frequency } \\
\text { of contact } \\
\text { average }\end{array}$ & $\begin{array}{c}\text { usage } \\
\text { experience } \\
\text { average }\end{array}$ & \multicolumn{2}{c}{ correlation } \\
male & 1.94 & 1.34 & 0.20 & 0.00 \\
female & 1.63 & 1.03 & 0.25 & 0.00 \\
$13 \sim 18$ & 1.65 & 1.05 & 0.00 & 0.97 \\
$19 \sim 39$ & 1.90 & 1.20 & 0.27 & 0.00 \\
$40 \sim 59$ & 1.71 & 1.26 & 0.28 & 0.00 \\
60 & 1.80 & 1.17 & 0.17 & 0.37 \\
\hline \hline
\end{tabular}

2) Two-dimensional cross tab analysis

TABLE III: Two-Dimensional CRosS TAB ANALYSIS BETWEEN ONLINE CONTACT OF SEXUAL CONTENTS AND ACT OF PROSTITUTION

\begin{tabular}{|c|c|c|c|c|c|}
\hline & & $\begin{array}{r}\text { Have no } \\
\text { xperience }\end{array}$ & $\begin{array}{l}\text { Have no } \\
\text { experience, } \\
\text { but feel } \\
\text { tempted to } \\
\text { do }\end{array}$ & $\begin{array}{c}\text { Have } \\
\text { experience } \\
\text { in }\end{array}$ & Total \\
\hline \multirow{3}{*}{$\begin{array}{l}\text { (1) Do } \\
\text { not } \\
\text { contract } \\
\text { at all }\end{array}$} & Frequency & 196 & 15 & 3 & 214 \\
\hline & Row \% & $91.6 \%$ & $7.0 \%$ & $1.4 \%$ & $100.0 \%$ \\
\hline & Column \% & $47.1 \%$ & $22.1 \%$ & $18.8 \%$ & $42.8 \%$ \\
\hline \multirow{3}{*}{$\begin{array}{l}\text { (2) Not } \\
\text { much } \\
\text { contract }\end{array}$} & Frequency & 153 & 27 & 7 & 187 \\
\hline & Row \% & $81.8 \%$ & $14.4 \%$ & $3.7 \%$ & $100.0 \%$ \\
\hline & Column $\%$ & $36.8 \%$ & $39.7 \%$ & $43.8 \%$ & $37.4 \%$ \\
\hline \multirow{3}{*}{$\begin{array}{l}\text { (3) often } \\
\text { contract }\end{array}$} & Frequency & 62 & 19 & 5 & 86 \\
\hline & Row \% & $72.1 \%$ & $22.1 \%$ & $5.8 \%$ & $100.0 \%$ \\
\hline & Column \% & $14.9 \%$ & $27.9 \%$ & $31.3 \%$ & $17.2 \%$ \\
\hline \multirow{3}{*}{$\begin{array}{l}\text { (4) Very } \\
\text { often } \\
\text { contract }\end{array}$} & Frequency & 5 & 7 & 1 & 13 \\
\hline & Row \% & $38.5 \%$ & $53.8 \%$ & $7.7 \%$ & $100.0 \%$ \\
\hline & Column \% & $1.2 \%$ & $10.3 \%$ & $6.3 \%$ & $2.6 \%$ \\
\hline \multirow[t]{3}{*}{ Total } & Frequency & 416 & 68 & 16 & 500 \\
\hline & Row \% & $83.2 \%$ & $13.6 \%$ & $3.2 \%$ & $100.0 \%$ \\
\hline & Column \% & $100.0 \%$ & $100.0 \%$ & $100.0 \%$ & $100.0 \%$ \\
\hline
\end{tabular}

Table III showed that Using of prostitution people are 3.2\% (16 people) of the total 500 people. 16 people, who often faced to genitals exposed, sexual activity, similar sexual act describe information is $37.6 \%$ (6 people), when saw the expected frequency, those who actual frequency can be seen higher than expected frequency. Impulsive too, can see that the better feel often contacted people more than do not contracted. Saw the respondents according to gender, for women (shown in Table IV). Although not use prostitution, often contact the group was more do not contact the groups than, expected frequency was higher than the actual frequency in impulses. Accordingly, in case of women also, not use prostitution, but in impulse was affected. 
TABLE IV: TWO-DIMENSIONAL CROSS TAB ANALYSIS BETWEEN ONLINE CONTACT OF SEXUAL CONTENTS AND ACT OF PROSTITUTION FOR FEMALE

\begin{tabular}{|c|c|c|c|}
\hline $\begin{array}{l}\text { Have no } \\
\text { experience }\end{array}$ & $\begin{array}{l}\text { Have no } \\
\text { experience, } \\
\text { but feel } \\
\text { tempted to } \\
\text { do }\end{array}$ & $\begin{array}{l}\text { Have } \\
\text { experience } \\
\text { in }\end{array}$ & Total \\
\hline 122 & 1 & & 123 \\
\hline $99.2 \%$ & $0.8 \%$ & & $100.0 \%$ \\
\hline $54.2 \%$ & $12.5 \%$ & & $52.8 \%$ \\
\hline 75 & 3 & & 78 \\
\hline $96.2 \%$ & $3.8 \%$ & & $100.0 \%$ \\
\hline $33.3 \%$ & $37.5 \%$ & & $33.5 \%$ \\
\hline 26 & 2 & & 28 \\
\hline $92.9 \%$ & $7.1 \%$ & & $100.0 \%$ \\
\hline $11.6 \%$ & $25.0 \%$ & & $12.0 \%$ \\
\hline 2 & 2 & & 4 \\
\hline $50.0 \%$ & $50.0 \%$ & & $100.0 \%$ \\
\hline $0.9 \%$ & $25.0 \%$ & & $1.7 \%$ \\
\hline 225 & 8 & & 233 \\
\hline $96.6 \%$ & $3.4 \%$ & & $100.0 \%$ \\
\hline $100.0 \%$ & $100.0 \%$ & & $100.0 \%$ \\
\hline
\end{tabular}

B. The Correlation between Violent Sexual Contents and Utilization of Prostitution

\section{1) Correlation analysis}

TABLE V: CORRELATION ANALYSIS BETWEEN ONLINE CONTACT OF VIOLENT SEXUAL CONTENTS AND ACT OF PROSTITUTION

\begin{tabular}{ccccc}
\hline \hline & \multicolumn{2}{c}{$\begin{array}{c}\text { frequency } \\
\text { of contact }\end{array}$} & $\begin{array}{c}\text { usage } \\
\text { experience }\end{array}$ & \multicolumn{2}{c}{ correlation } \\
\cline { 2 - 5 } & average & average & $\mathrm{R}$ & $\mathrm{P}$ \\
\hline male & 1.70 & 1.34 & 0.18 & 0.00 \\
\hline female & 1.50 & 1.03 & 0.24 & 0.00 \\
\hline $13 \sim 18$ & 1.35 & 1.05 & -0.13 & 0.30 \\
\hline $19 \sim 39$ & 1.67 & 1.20 & 0.13 & 0.06 \\
\hline $40 \sim 59$ & 1.61 & 1.26 & 0.29 & 0.00 \\
\hline 60 & 1.70 & 1.17 & 0.39 & 0.03 \\
\hline \hline
\end{tabular}

Table V showed that in case adolescents group, the ages of 19 and 39 were not has a correlation at between contract of violent sexual contents and utilization of prostitution, but the rest all of groups has a correlation that P-values less than 0.05 .

\section{2) Two-dimensional cross tab analysis}

Table VI showed that Among 16 people with prostitution, $25 \%$ was often faced to violent sexual contents on the Internet. This is relative to high levels, compared with a portion only $16.5 \%$ of the male respondents often access to violent sexual contents from the internet.

Thus, a man who experienced prostitution, Even can be seen that a lot of contract experience for violent sexual information on the Internet. So that was significant impact to utilization of prostitution. Notable is very often contract to violent sexual information people do not utilization of prostitution, but nine people who did not contract prostitution appeared to utilization of prostitution. This is expected sometimes rather than often more stimulate sexual curiosity.

\section{The Correlation between Child Pornography Contents} and of Act Prostitution

\section{1) Correlation analysis}

Table VII showed that in case an adolescents group, a more than 60 years olds group were not has a correlation at between contract of child pornography contents and utilization of prostitution, but the rest all of groups has a correlation that P-values less than 0.05 .

TABLE VI: TWO-Dimensional CROSS TAB ANALYSIS BETWEEN ONLINE CONTACT OF VIOLENT SEXUAL CONTENTS AND ACT OF PROSTITUTION

\begin{tabular}{|c|c|c|c|c|c|}
\hline & & $\begin{array}{l}\text { Have no } \\
\text { experience }\end{array}$ & $\begin{array}{l}\text { Have no } \\
\text { experience, } \\
\text { but feel } \\
\text { tempted to } \\
\text { do }\end{array}$ & $\begin{array}{l}\text { Have } \\
\text { experience } \\
\text { in }\end{array}$ & Total \\
\hline \multirow{3}{*}{$\begin{array}{l}\text { (1) Do } \\
\text { not } \\
\text { contract } \\
\text { at all }\end{array}$} & Frequency & 239 & 24 & 3 & 266 \\
\hline & Row \% & $\begin{array}{l}89.8 \\
\%\end{array}$ & $9.0 \%$ & $1.1 \%$ & $100.0 \%$ \\
\hline & Column $\%$ & $\begin{array}{l}57.5 \\
\%\end{array}$ & $35.3 \%$ & $18.8 \%$ & $53.2 \%$ \\
\hline \multirow{3}{*}{$\begin{array}{l}\text { (2) Not } \\
\text { much } \\
\text { contract }\end{array}$} & Frequency & 135 & 26 & 9 & 170 \\
\hline & Row \% & $\begin{array}{l}79.4 \\
\%\end{array}$ & $15.3 \%$ & $5.3 \%$ & $100.0 \%$ \\
\hline & Column \% & $\begin{array}{l}32.5 \\
\% \\
\end{array}$ & $38.2 \%$ & $56.3 \%$ & $34.0 \%$ \\
\hline \multirow{3}{*}{$\begin{array}{l}\text { (3) often } \\
\text { contract }\end{array}$} & Frequency & 37 & 17 & 4 & 58 \\
\hline & Row $\%$ & $\begin{array}{l}63.8 \\
\%\end{array}$ & $29.3 \%$ & $6.9 \%$ & $100.0 \%$ \\
\hline & Column \% & $8.9 \%$ & $25.0 \%$ & $25.0 \%$ & $11.6 \%$ \\
\hline \multirow{3}{*}{$\begin{array}{l}\text { (4) Very } \\
\text { often } \\
\text { contract }\end{array}$} & Frequency & 5 & 1 & 0 & 6 \\
\hline & Row \% & $\begin{array}{l}83.3 \\
\%\end{array}$ & $16.7 \%$ & $0.0 \%$ & $100.0 \%$ \\
\hline & Column \% & $1.2 \%$ & $1.5 \%$ & $0.0 \%$ & $1.2 \%$ \\
\hline \multirow[t]{3}{*}{ Total } & Frequency & 416 & 68 & 16 & 500 \\
\hline & Row \% & $\begin{array}{l}83.2 \\
\%\end{array}$ & $13.6 \%$ & $3.2 \%$ & $100.0 \%$ \\
\hline & Column \% & $\begin{array}{l}100.0 \\
\%\end{array}$ & $100.0 \%$ & $100.0 \%$ & $100.0 \%$ \\
\hline
\end{tabular}

TABLE VII: CORRELATION ANALYSIS BETWEEN ONLINE CONTACT OF CHILD PORNOGRAPHY CONTENTS AND ACT OF PROSTITUTION

\begin{tabular}{lllll}
\hline \hline & \multicolumn{2}{l}{$\begin{array}{l}\text { frequency } \\
\text { of contact }\end{array}$} & \multicolumn{2}{l}{ usage } \\
& experience & correlation & \\
\hline average & average & $\mathrm{R}$ & $\mathrm{P}$ \\
\hline male & 1.43 & 1.34 & 0.20 & 0.00 \\
\hline female & 1.33 & 1.03 & 0.29 & 0.00 \\
\hline $13 \sim 18$ & 1.32 & 1.05 & -0.13 & 0.32 \\
\hline $40 \sim 39$ & 1.41 & 1.20 & 0.15 & 0.02 \\
\hline 60 & 1.38 & 1.26 & 0.32 & 0.00 \\
\hline \hline
\end{tabular}

\section{2) Two-dimensional cross tab analysis}

Table VIII showed that Among 16 people with prostitution, $18.8 \%$ was often faced, child pornography on the Internet. The expected frequency of often contact response group show much lower than does not touch response group, But the actual utilization rate was relatively high. Therefore, contact of information was had significant influence to the actual act of prostitution. Also child pornography, same violence sexual information, not actual available actual act of prostitution at the very often response. This when it comes to contract the unusual obscene prostitution information as child pornography and violence sexual violence, Rather seems to be caused the repulsion.

\section{The correlation between cyber sex trafficking and act prostitution}

\section{1) Correlation analysis}

Table IX showed that in case an adolescents group, a more than 60 years olds group were not has a correlation at between 
contract of sex trade information and utilization of prostitution, but the rest all of groups has a correlation that P-values less than 0.05 .

TABLE VIII: TWO-DIMENSIONAL CROSS TAB ANALYSIS BETWEEN ONLINE CONTACT OF CHILD PORNOGRAPHY CONTENTS AND ACT OF PROSTITUTION

\begin{tabular}{|c|c|c|c|c|c|}
\hline & & $\begin{array}{l}\text { Have no } \\
\text { experience }\end{array}$ & $\begin{array}{l}\text { Have no } \\
\text { experience, } \\
\text { but feel } \\
\text { tempted to } \\
\text { do }\end{array}$ & $\begin{array}{l}\text { Have } \\
\text { experience } \\
\text { in }\end{array}$ & Total \\
\hline \multirow{3}{*}{$\begin{array}{l}\text { (1) Do } \\
\text { not } \\
\text { contract } \\
\text { at all }\end{array}$} & Frequency & 310 & 36 & 7 & 353 \\
\hline & Row \% & $87.8 \%$ & $10.2 \%$ & $2.0 \%$ & $100.0 \%$ \\
\hline & Column $\%$ & $74.5 \%$ & $52.9 \%$ & $43.8 \%$ & $70.6 \%$ \\
\hline \multirow{3}{*}{$\begin{array}{l}\text { (2) Not } \\
\text { much } \\
\text { contract }\end{array}$} & Frequency & 83 & 20 & 6 & 109 \\
\hline & Row \% & $76.1 \%$ & $18.3 \%$ & $5.5 \%$ & $100.0 \%$ \\
\hline & Column \% & $20.0 \%$ & $29.4 \%$ & $37.5 \%$ & $21.8 \%$ \\
\hline \multirow{3}{*}{$\begin{array}{l}\text { (3) often } \\
\text { contract }\end{array}$} & Frequency & 21 & 9 & 3 & 33 \\
\hline & Row \% & $63.6 \%$ & $27.3 \%$ & $9.1 \%$ & $100.0 \%$ \\
\hline & Column \% & $5.0 \%$ & $13.2 \%$ & $18.8 \%$ & $6.6 \%$ \\
\hline \multirow{3}{*}{$\begin{array}{l}\text { (4) Very } \\
\text { often } \\
\text { contract }\end{array}$} & Frequency & 2 & 3 & 0 & 5 \\
\hline & Row \% & $40.0 \%$ & $60.0 \%$ & $0.0 \%$ & $100.0 \%$ \\
\hline & Column \% & $0.5 \%$ & $4.4 \%$ & $0.0 \%$ & $1.0 \%$ \\
\hline \multirow[t]{3}{*}{ Total } & Frequency & 416 & 68 & 16 & 500 \\
\hline & Row \% & $83.2 \%$ & $13.6 \%$ & $3.2 \%$ & $100.0 \%$ \\
\hline & Column \% & $100.0 \%$ & $100.0 \%$ & $100.0 \%$ & $100.0 \%$ \\
\hline
\end{tabular}

TABLE IX: CORRELATION ANALYSIS BETWEEN ONLINE CONTACT OF CYBER SEX TRAFFICKING AND ACT OF PROSTITUTION

\begin{tabular}{lllll}
\hline \hline & $\begin{array}{l}\text { frequency } \\
\text { of contact }\end{array}$ & \multicolumn{2}{l}{ usage } \\
& experience & correlation & \\
\cline { 2 - 5 } average & average & $\mathrm{R}$ & $\mathrm{P}$ \\
\hline male & 1.69 & 1.34 & 0.23 & 0.00 \\
\hline female & 1.48 & 1.03 & 0.25 & 0.00 \\
\hline $13 \sim 18$ & 1.35 & 1.05 & -0.11 & 0.36 \\
\hline $19 \sim 39$ & 1.64 & 1.20 & 0.20 & 0.00 \\
\hline $40 \sim 59$ & 1.61 & 1.26 & 0.33 & 0.00 \\
\hline 60 & 1.73 & 1.17 & 0.17 & 0.36 \\
\hline \hline
\end{tabular}

\section{2) Two-dimensional cross tab analysis}

Table X showed that Among 16 people with prostitution, $31.3 \%$ was often faced, prostitution information on the Internet. This is relative to high levels, compared with a portion only $17.7 \%$ of the male respondents in online prostitution information often encountered, and higher actual prostitution utilization than respondents often do not encountered. Therefore can see that prostitution information is a significant impact on use prostitution. In case of prostitution information, When do not encounted much information, feel the urge ratio was higher than the other information. That seem to feel the urge so grew curious, When got prostitution information; direct prostitution on use prostitution.

\section{CONCLUSIONS AND IMPLICATIONS}

In this study, which were studied the correlation between obscene the sex trade information and utilization of prostitution of all illegal obscene information. For this study, It provides usage experiences of each frequency of contact and actual prostitution divided four obscene prostitution information for 500 people in Korea.
The results of the survey, Contract frequency to illegal pornographic on the Internet and actual utilization of prostitution has a correlation.

For example, frequent contact group to find sexual contents on the Internet, Who actual utilization of prostitution and feel the urge ratio was relatively high compared with do not often groups. Therefore harmful information via the Internet was to have correlation at actual utilization of prostitution.

Thus, If not controlled properly about on the Internet, There is high probability of tort. Therefore, It is important to control activity about obscene contents information on the Internet.

TABLE X: Two-DimenSIONAL CROSS TAB ANALYSIS BETWEEN ONLINE CONTACT OF CYBER SEX TRAFFICKING AND ACT OF PROSTITUTION

\begin{tabular}{|c|c|c|c|c|c|}
\hline & & $\begin{array}{l}\text { Have no } \\
\text { experience }\end{array}$ & $\begin{array}{l}\text { Have no } \\
\text { experienc } \\
\text { e, but feel } \\
\text { tempted to } \\
\text { do }\end{array}$ & $\begin{array}{l}\text { Have } \\
\text { experience } \\
\text { in }\end{array}$ & Total \\
\hline \multirow{3}{*}{$\begin{array}{l}\text { (1) Do } \\
\text { not } \\
\text { contract } \\
\text { at all }\end{array}$} & Frequency & 109 & 22 & 3 & 134 \\
\hline & Row \% & $81.3 \%$ & $16.4 \%$ & $2.2 \%$ & $100.0 \%$ \\
\hline & Column \% & $57.1 \%$ & $36.7 \%$ & $18.8 \%$ & $50.2 \%$ \\
\hline \multirow{3}{*}{$\begin{array}{l}\text { (2) Not } \\
\text { much } \\
\text { contract }\end{array}$} & Frequency & 54 & 24 & 8 & 86 \\
\hline & Row $\%$ & $62.8 \%$ & $27.9 \%$ & $9.3 \%$ & $100.0 \%$ \\
\hline & Column \% & $28.3 \%$ & $40.0 \%$ & $50.0 \%$ & $32.2 \%$ \\
\hline \multirow{3}{*}{$\begin{array}{l}\text { (3) often } \\
\text { contract }\end{array}$} & Frequency & 26 & 13 & 3 & 42 \\
\hline & Row \% & $61.9 \%$ & $31.0 \%$ & $7.1 \%$ & $100.0 \%$ \\
\hline & Column \% & $13.6 \%$ & $21.7 \%$ & $18.8 \%$ & $15.7 \%$ \\
\hline \multirow{3}{*}{$\begin{array}{l}\text { (4) Very } \\
\text { often } \\
\text { contract }\end{array}$} & Frequency & 2 & 1 & 2 & 5 \\
\hline & Row $\%$ & $40.0 \%$ & $20.0 \%$ & $40.0 \%$ & $100.0 \%$ \\
\hline & Column \% & $1.0 \%$ & $1.7 \%$ & $12.5 \%$ & $1.9 \%$ \\
\hline \multirow[t]{3}{*}{ Total } & Frequency & 191 & 60 & 16 & 267 \\
\hline & Row \% & $71.5 \%$ & $22.5 \%$ & $6.0 \%$ & $100.0 \%$ \\
\hline & Column \% & $100.0 \%$ & $100.0 \%$ & $100.0 \%$ & $100.0 \%$ \\
\hline
\end{tabular}

\section{ACKNOWLEDGMENT}

This research was supported by the MSIP (Ministry of Science, ICT \& Future Planning), Korea, under the "Employment Contract based Master's Degree Program for Information Security" supervised by the KISA (Korea Internet Security Agency) (H2101-13-1001)

\section{REFERENCES}

[1] Korea Communications Commission "2012 Internet utilization Research on the actual condition," 2012.

[2] Korea Internet \& Security Agency, " 2012 Wireless internet actuality of utilization research," 2012.

[3] Korea Communications Standards Commission, "Study of SNS illegal harmful actual condition and plan for reaction," 2011.

[4] Korea Communications Standards Commission, "2012 Korea communications standards yearbook," 2012.

[5] Row of Korea, "Act on the Punishment of Procuring Prostitution Act, etc.," Legislation No. 11731.

[6] Kim et al, "Analysis of correlation between contacts to cyber obscene materials and sex crime of high school students," Journal of Korea Contents Association, vol. 11, no. 6, pp. 8-17, 2011.

[7] Park, "Child sex offenses and child pornographies on the internet," The Korean Association of Criminology, vol. 18, no. 1, pp. 145-182, 2007.

[8] Kim, "A study on understanding of adolescent sex offences and pornography addiction," Korean Association of addiction Crime, vol. 2, no. 1, pp. 47-71, 2012. 
[9] N. Hong, "The relationship between adolescents` exposure to internet pornography and deviant sexual activities: focusing on mediated effects of perceptional factors," Korea Youth Research Association, vol. 19 , no. 9, pp. 93-125, 2012.

[10] N. Hong, "Effects of exposure to internet phonography on sexual assault and prostitution of adolescents," Korean Society of Child Welfare, vol. 40, pp. 9-39, 2012

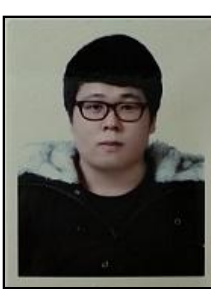

Chanhee Han was born in Incheon, Republic of Korea, on November 26, 1987.

He has got his bachelor of business administration from Sangmyung University, Republic of Korea, in 2013.

Now he is perusing his master's degree of information security management in Sangmyung University, Republic of Korea.

His research interest is policy of security.

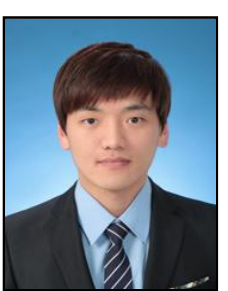

Taehwan Kim was born in Hwasung, Republic of Korea, on July 5, 1987.

He has got his bachelor of business administration from Sangmyung University, Republic of Korea, in 2013.

Now, he is perusing his master's degree of information security management in Sangmyung University, Republic of Korea.

His research interest is security management.

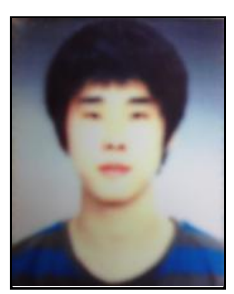

Youngsu Son was born on November 13, 1987, in Yangsan, Republic of Korea.

He has got his bachelor of e-business administration from Kyungnam University, Republic of Korea, in 2013.

Now, he is perusing his master's degree of information security management in Sangmyung University, Republic of Korea.

His research interest is policy of security.

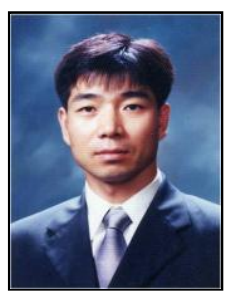

Jinho Yoo is a professor at Sangmyung University. He received his $\mathrm{Ph}$. D. in information management and security from Graduate School of Information Management and Security at Korea University. Prior to joining Sangmyung University, $\mathrm{He}$ worked as the director of Internet Culture Development Department at KISA (Korea Internet and Security Agency) and as a principal consultant of CRM and data mining at IBM Korea. His research interests include issues related to information security policy and management. 